\title{
PENINGKATAN KEMAMPUAN PENGELOLA UKM SEPATU DALAM MENGGUNAKAN TEKNOLOGI DAN INFORMASI DI DESA SAMBIROTO-SOOKO-KABUPATEN MOJOKERTO
}

\author{
Sugeng Mulyono ${ }^{1^{*}}$ dan Jamal Abdul Nasir ${ }^{1}$ \\ ${ }^{1}$ Program Studi Manajemen, Fakultas Ekonomi dan Bisnis, Universitas Gajayana \\ Jl. Mertojoyo-Dinoyo, Malang 65144 \\ *Korespondensi penulis, email: sugengmulyono45@yahoo.co.id
}

\begin{abstract}
Abstrak: Tujuan pengabdian masyarakat ini adalah mengoptimalkan kinerja pengelola Usaha Kecil Menengah (UKM) sepatu dalam tatakelola keuangan, pemasaran dan kemampuan memanfaatkan teknologi dan informasi pemasaran. Metode pelaksanaan dengan mengombinasikan pelatihan klasikal, pendampingan dan bantuan komputer untuk menstimulir pengelola usaha sepatu mengimplementasikan materi pelatihan. Pelatihan dan pendampingan berhasil meningkatkan kemampuan pengelola UKM sepatu, meskipun masih belum optimal, dalam tatakelola keuangan, metode pemasaran dan pemanfaatan website untuk pemasaran.
\end{abstract}

Kata kunci: Kinerja, pelatihan, pendampingan dan UKM.

\begin{abstract}
The purpose of this community service is to optimize the performance of SMEs managers of shoes financial governance, marketing and the ability to utilize technology and marketing information. Method of execution by combining classical training, mentoring and computer support to stimulate shoe business managers to implement training materials. Training and mentoring successfully improving the management capabilities of SMEs of shoes, although still not optimal, in the financial governance, marketing methods and website utilization for marketing.
\end{abstract}

Keywords: Performance, training, mentoring and SEMs.

\section{PENDAHULUAN}

Menurut catatan kantor Kementerian Negara Koperasi dan Usaha Mikro Kecil dan Menengah (UMKM) bahwa dalam kurun waktu 4 tahun terakhir, perkembangan UMKM cukup signifikan dan mampu menjadi penopang pertumbuhan ekonomi nasional serta penyedia lapangan kerja. Pada tahun 2011 UMKM mampu menyerap tenaga kerja sebesar 101,7 juta orang atau 97,24 persen dari total penyerapan tenaga kerja yang ada. Jumlah ini meningkat sebesar 0,2 persen dibandingkan dengan tahun 2010 dan meningkat 0,9 persen dibanding tahun 2008 (Dinas Koperasi, 2012).

Peranan UMKM sebagai katub pengaman stagnasi ekonomi dan mempunyai prospek pertumbuhan yang baik perlu dipertahankan bahkan ditingkatkan. Sektor ini sudah teruji ketangguhannya dalam menghadapi berbagai kejutan ekonomi dan berperanan penting sebagai penyedia lapangan kerja dalam skala besar (M. Achmadi, 1995). Untuk menjamin optimisme perkembangan UMKM dimasa depan memerlukan penataan dan penguatan kompetensi pengelola organisasinya. Daya dukung permodalan, manajemen dan SDM yang berkualitas tinggi merupakan keharusan untuk optimalisasi kinerja UMKM secara berkelanjutan. Namun demikian, sampai saat ini UMKM masih dihadapkan pada sejumlah kendala yang berupa keterbatasan akses pasar, permodalan, pengelolaan bisnis masih bersifat tradisional, profesionalitas pengelolaan rendah dan belum optimal kinerja manajerialnya (Tambunan, Tulus T.H., 2008).

Sebagai bagian integral dari UMKM, keberadaan UKM mempunyai peranan besar dalam penyediaan lapangan kerja di Pedesaan, utamanya pada tenaga kerja yang berpendidikan dan berketrampilan rendah. Sektor usaha ini cukup signifikan dalam penyerapan tenaga kerja pada penduduk di desa sehingga keberadaannya sangat membantu bagi upaya penanggulangan kemiskinan dan peningkatan penghasilan masyarakat (Mubyarto, 2001). Untuk itu sektor usaha ini perlu ditingkatkan kinerjanya agar tetap bisa survive dan bahkan berkembang ditengah persaingan bisnis yang semakin ketat.

Upaya optimalisasi kinerja UKM dapat dilakukan melalui peningkatan kemampuan SDMnya dalam mengelola bisnis. Sebab, sumber daya manusia 
memegang peranan penting dalam menentukan daya survival organisasi dalam jangka pandek maupun jangka panjang serta merupakan sumber keunggulan kompetitif di tengah lingkungan bisnis yang semakin kompleks dan penuh persaingan (Morck, F., M. Hall dan E.Vall. 2003).

Seiring dengan perubahan lingkungan yang semakin cepat, menuntut setiap organisasi untuk segera melakukan revitalisasi SDMnya melalui proses pembelajaran secara berkesinambungan agar memiliki daya tanggap dan daya adaptasi yang cepat terhadap dinamika eksternalnya. Kemajuan teknologi informasi dan ilmu pengetahuan serta perubahan ekonomi mengharuskan organisasi ataupun bisnis membuat transformasi pengetahuan dan ketrampilan untuk merespons perubahan lingkungan agar dapat survive dan berkembang (Robbins, S.P. \& Judge A.Timothy, 2009).

Menghadapi perubahan yang terkadang tidak dapat diprediksi kemunculannya, maka organisasi ataupun individu tidak dapat menghadapinya dengan cara menentang melainkan perlu mengelolanya melalui pengadaptasian diri. Dalam kindisi seperti itu, maka dianjurkan kepada individu yang ingin bersaing dalam lingkungan bisnis harus menjadikan pribadi maupun organisasinya sebagai pembelajar melalui cara terus menerus beradaptasi dengan lingkungan (Senge, 1994). Kemampuan mengantisipasi perubahan ini tergantung pada kreativitas, inovasi dan skill para anggota organisasi. Melalui peningkatan kualitas SDM dalam tatakelola usaha, penguasaan teknologi dan informasi serta strategi pemasarannya, mka diharapkan dapat membantu UKM untuk meningkatkan kinerja usahanya.

\section{ANALISIS SITUASI}

UKM sepatu ini mulai didirikan pada tahun 1988 dengan beralamatkan di desa Sambiroto, Sooko, Kabupaten Mojokerto. Secara tradisional Desa Sambiroto, bahkan Kecamatan Sooko memang dikenal sebagai sentra home industry sepatu. Pada awal pendirian usaha, UKM ini mempekerjakan 8 orang dengan kapasitas produksi per-hari 72 pasang. Proses produksi mulai dari awal sampai menjadi produk siap jual semuanya dilakukan dengan mengandalkan pada ketrampilan pengrajin, sehingga kapasitas produksi maupun standart kualitasnya belum bisa stabil. Wilayah pemasaran produk, masih terbatas di Jawa Timur, utamanya Pasar Turi Surabaya. Pengrajin belum mampu untuk memenuhi semua permintaan pasar karena keterbatasan kapasitas produksinya.
Seiring dengan pengalaman mengelola usaha dan peningkatan permintaan sepatu, maka mulai tahun 2003, pemilik/pengelola memutuskan untuk melakukan modernisasi proses produksi. Proses produksi yang semula bertumpu pada ketrampilan pekerja ditingkatkan dengan menambah alat produksi berupa mesin pencetakan. Modernisasi dalam proses produksi, yakni dari sistem produksi manual yang mengandalkan ketrampilan manusia ke proses produksi dengan menggunakan mesin membawa dampak positif berupa peningkatan kapasitas produksi, standarisasi kualitas produk maupun ragam model yang diproduksi juga bervariasi, yakni sepatu sekolah, sepatu futsal dan sepatu bola. Kapasitas produksi yang semula hanya 6 dosen perhari meningkat menjadi 75 dosen perhari.

Setelah beroperasi selama 25 tahun, pada saat ini perusahaan telah mengalami kemajuan yang cukup signifikan. Kapasitas produksi per hari pada tahun 2013 ini telah mencapai 1200 pasang dengan jumlah karyawan sebanyak 60 orang. Peningkatan kapasitas produksi maupun ragam model yang dihasilkan mengharuskan perusahaan mengembangkan jangkauan wilayah pemasaran ke propinsi Sumatra dan Kalimantan. Perluasan jangkauan wilayah pemasaran produk dengan sendirinya memerlukan model pemasaran yang tidak lagi konvensional, melainkan juga perlu memanfaatkan teknologi dan informasi agar pemasaran produk dapat dilakukan secara efektif-efisien dalam cakupan wilayah yang luas. Namun demikian, dari sisi tatakelola keuangan, SDM maupun pemasarannya sektor usaha ini masih menerapkan sistem konvesional dan belum memanfaatkan teknologi dan informasi. Adapun kondisi yang sedang berlangsung pada UKM sepatu dalam pembukuan, pemasaran dan pemanfaatan teknologi informasi akan dipaparkan berikut ini.

\section{Bidang Akuntansi}

Implementasi bidang akuntansi pada UKM sepatu, masih belum dalaksanakan secara optimal. Pelaku usaha kurang begitu memperhatikan pencatatan arus keuangan perusahaan. Mereka berpikir bahwa kegiatan itu kurang begitu penting bagi kelangsungan usaha. Hal ini bisa dipahami, mengingat selama 25 tahun menjalankan usaha, mereka tidak menggunakan metode pencatatan yang benar. Mereka "mengalir" begitu saja dalam mengelola arus keluar masuk keuangan perusahaan. Fenomena ini memperkuat pendapat bahwa mengubah kebiasaan, sikap dan perilaku memang bukan pekerjaan mudah, dan untuk dapat mengubah prilaku tersebut memerlukan waktu yang relatif lama. 
Urgensi melakukan pembukuan keuangan perusahaan secara benar perlu secara intens disosialisasikan kepada pengelola UKM sepatu agar tumbuh kesadaran tentang manfaat pengetahuan dan ketrampilan ini dalam memperbaiki pengelolaan usaha. Fakta inilah yang dipakai sebagai dasar oleh tim pelaksana pengabdian untuk penyusunan modul tentang pembukuan. Tentu saja materi modul disesuaikan dengan karakteristik dan kebutuhan pengelola UKM. Modul inilah yang akan disampaikan pada saat pelatihan dan sekaligus sebagai panduan bagi mitra kerja dalam melakukan pencatatan arus keuangan perusahaan.

\section{Pemasaran}

Kunci kemajuan usaha terletak pada seberapa besar kesediaan pasar untuk menerima barang yang ditawarkan oleh produsen. Artinya, kelangsungan suatu usaha sangat tergantung pada seberapa banyak dan seberapa lama produk yang ditawarkan bisa diterima oleh konsumen. Untuk bisa menarik minat konsumen membeli produk tidak terlepas dari strategi pemasaran dan pelayanan. Kedua hal tersebut merupakan kunci bagi kemajuan usaha. Dalam hal ini, UKM sepatu sudah melaksanakan konsep pemasaran dan pelayanan secara baik, namun pelaksanaannya masih konvensional dan belum menggunakan perangkat teknologi dan informasi sehinga daya jangkau wilayah pemasaran relatif terbatas.

Selama ini wilayah pemasaran sebagaian besar di Jawa Timur khususnya Surabaya (Pasar Turi), Jawa Tengah, Sumatra dan Kalimantan. Biasanya, konsumen akan melakukan pilihan terhadap salah satu contoh produk (sepatu) atau terkadang calon konsumen menentukan desain sendiri kemudian memesan produknya pada pengrajin UKM sepatu. Jika pesanan dalam jumlah besar, maka pengrajin akan membuat model terlebih dahulu dan kemudian diberikan kepada pemesan. Jika pemesan merasa sesuai dengan model yang ditawarkan, maka mereka akan membuat kontrak kerja untuk penyelesaian seluruh pesanan yang sesuai dengan model tersebut.

Jangkauan wilayah pemasaran sangat berpengaruh pada kelangsungan produksi UKM sepatu. Keberhasilan memperluas wilayah pemasaran dan segmentasi pasar akan berpengaruh terhadap jumlah penjualan sepatu. Karena itu, pelaku usaha merasa perlu difasilitasi dalam meningkatkan kemampuan menggunakan teknologi dan informasi untuk memasarkan produknya agar dapat dikenal konsumen dalam skala luas.

\section{Pemanfaatan Teknologi dan Informasi}

Pemanfaatan teknologi dan informasi sudah menjadi kebutuhan utama dalam dunia usaha. Kehadiran teknologi ini sangat membantu dalam memudahkan pengelolaan usaha, transaksi barang maupun memasarkan produk agar bisa dikenal konsumen dalam skala luas. Meskipun penggunaan teknologi dan informasi sangat penting bagi pengelolaan bisnis, namun pengelola UKM sepatu masih belum menggunakannya. Hal ini disebabkan mereka masih belum mempunyai pengetahuan dan ketrampilan dalam memanfaatkan teknologi dan informasi. Untuk itu, maka pada pelaksanaan pengabdian ini diberikan materi tentang tata cara pemanfaatan teknologi dan informasi serta manfaatnya dalam membantu mengembangkan usaha.

\section{METODE PELAKSANAAN}

Memperhatikan karakteristik pengusaha sepatu beserta permasalahan yang dihadapi, maka metode pelaksanaan pengabdian kepada masyarakat ini menggunakan perpaduan antara pelatihan tutorial, praktek, bantuan peralatan komputer dan pendampingan.

\section{PELAKSANAAN KEGIATAN}

Kegiatan pelatihan dan pendampingan bagi UKM sepatu dalam rangka meningkatkan kemampuan tatakelola keuangan dan pemasaran dengan memanfaatkan teknologi informasi dilaksanakan selama 9 bulan, terhitung sejak disetujuinya proposal kegiatan, yakni bulan Maret sampai dengan pertengahan Desember 2013. Lokasi kegiatan berada di desa Sambiroto, Kecamatan Sooko Kabupaten Mojokerto. Adapun rangkaian pelaksanaan kegiatan dipaparkan berikut ini.

Persiapan dimaksudkan untuk menjelaskan kepada tim tentang subtansi kegiatan pengabdian kepada masyarakat dan serangkaian langkah operasionalisasi kedalam tugas pokok dan fungsi. Kegiatan ini dimaksudkan agar anggota tim memiliki pemahaman yang padu tentang pelaksanaan pelatihan dan pendampingan pada pengelola UKM sepatu agar dapat efektif.

Selanjutnya melakukan survei pendahuluan dengan maksud untuk menggali informasi secara mendalam tentang kondisi yang sedang dihadapi pengelola UKM sepatu terkait dengan pengelolaan keuangan, akses informasi, pemasaran serta penguasaan teknologi dan informasi. Kegiatan ini untuk mengumpulkan data untuk melaksanakan kegiatan dengan metode yang sesuai dengan kebutuhan pengelola UKM sepatu. 
Penyusunan modul menyesuaikan kebutuhan peserta, yakni kandungan isinya yang sederhana dan mudah dipahami. Isi modul pelatihan meliputi: kiat sukses berwirausaha, manajemen keuangan, pemasaran, aplikasi website dan akses internet. Materi modul pelatihan disusun dengan memperhatikan kebutuhan pengelola UKM. Materi modul disusun berdasarkan pada hasil pengamatan maupun wawancara secara mendalam dengan pengelola. Modul dirancang sesuai dengan tingkat pengetahuan dan ketrampilan yang dikuasai oleh mitra kerja.

Modul pelatihan disusun berdasarkan kebutuhan pengelolaan UKM sepatu dan sedapat mungkin mudah untuk dipraktekkan. Modul ini merupakan acuan bagi peserta latihan dalam meningkatkan pengetahuan dan ketrampilan untuk diterapkan dalam mengelola usahanya. Modul disusun sesederhana mungkin agar mudah dipahami dan diimplementasikan. Adapun modul pelatihan meliputi: (1) kewirausahaan, (2) akuntansi untuk bisnis UKM, (3) manajemen pemasaran, dan (4) dasar-dasar penggunaaan teknologi informasi dan metode mengoperasionalkan website.

Selanjutnya melakukan desain website bagi UKM sepatu. Pemanfaatan website diharapkan dapat mengoptimalkan kinerja pemasarannya. Sebab itu, perlu adanya website yang memuat profil perusahaan maupun produk yang dihasilkan (sepatu). Mengingat saat ini banyak konsumen yang menggunakan internet untuk melihat maupun memesan suatu produk. Agar pengelola UKM sepatu dapat lebih optimal dalam memasarkan produknya.

Sesuai dengan masukan dari pengelola UKM, maka konten yang dimuat dalam website meliputi: profil perusahaan, jenis produk, harga produk, tatacara pembelian dan cara pembayaran. Selain itu pada website juga bisa mendeteksi berapa pengunjung yang sudah mengaksesnya agar pengelola UKM dapat melihat efektivitas website tersebut sebagai media memasarkan produk.

Pelatihan dirancang dengan model komunikasi aktif dua arah dengan dipandu oleh para instruktur yang kompeten dibidangnya. Pelaksanaan pelatihan diikuti oleh pengelola UKM sepatu. Metode pelatihan berupa ceramah dengan durasi waktu @ 75 menit dalam setiap sesinya. Selanjutnya dilakukan tanya jawab maupun peragaan materi selama \pm 75 menit. Melalui metode komunikasi dua arah ini diharapkan peserta pelatihan bisa memahami materi yang diberikan sehingga memudahkan mereka dalam penerapannya.
Materi pelatihan yang disampaikan menyesuaikan dengan karakteristik sasaran. Untuk itu materi pelatihan dirancang selugas mungkin agar mudah untuk dipahami dan dilaksanakan. Adapun materi yang diberikan kepada peserta pelatihan tahap I meliputi: kewirausahaan, pemasaran dan akuntansi.

Sedangkan pada tahap II, materi pelatihan yang disampaikan adalah dasar-dasar komputer dan pengoperasian website. Pada metode pelatihan ini, durasi waktu untuk pemaparan materi @ 75 menit dalam setiap sesinya. Selanjutnya dilakukan tanya jawab maupun peragaan materi selama \pm 75 menit. Melalui metode ceramah dan praktek ini diharapkan peserta pelatihan bisa lebih memahami materi yang diberikan.

Selama pelatihan berlangsung, respons peserta cukup baik. Hal ini nampak dari banyaknya pertanyaan maupun pernyataan dari para peserta tentang materi yang disampaikan. Mereka juga sangat antusias menanyakan tatacara mengoperasionalkan website dan manfaat penggunaannya untuk pemasaran produk. Suasana pelatihan terasa "hidup" dikarenakan instruktur dan peserta terlibat dalam diskusi yang intensif. Adapun photo kegiatan pelatihan dapat dilihat pada gambar. 1-2.
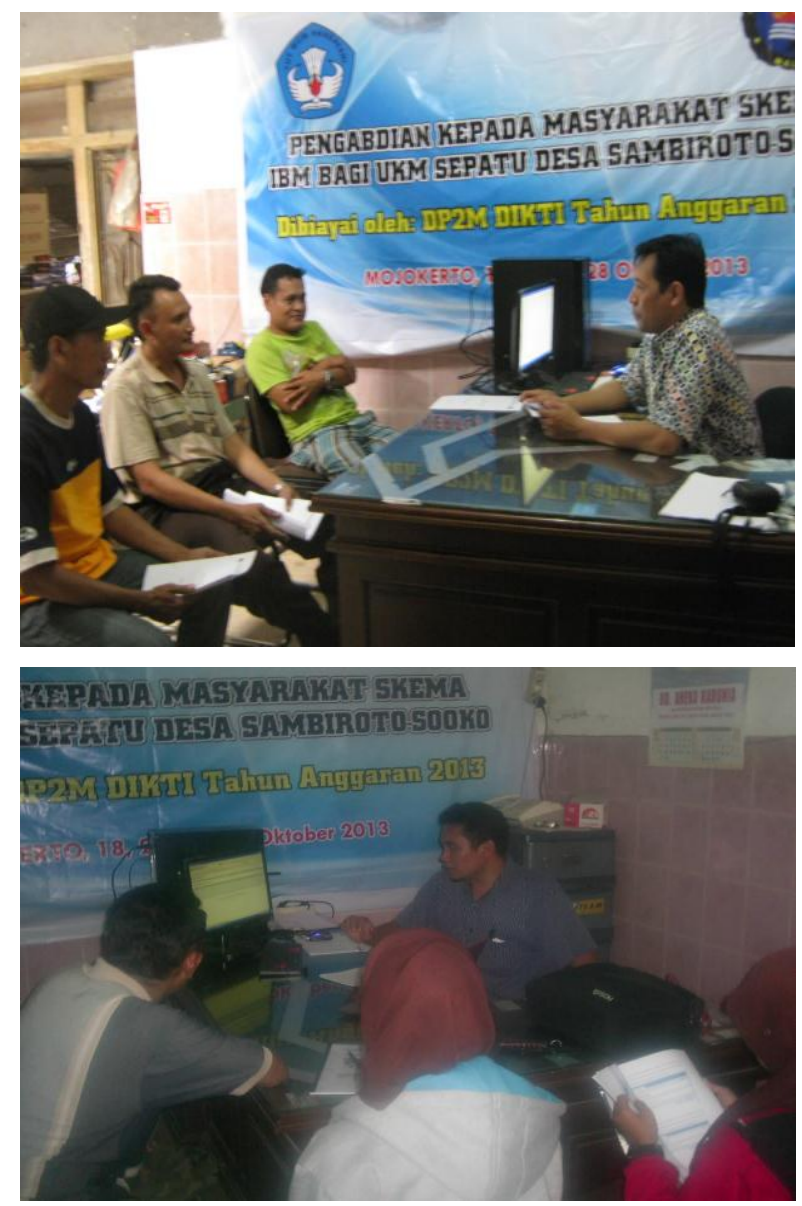


\section{PENDAMPINGAN}

Pendampingan dilakukan sebagai sarana monitoring, dan memandu pengelola UKM sepatu untuk menerapkan teori yang diperoleh. Secara spesifik kegiatan ini meliputi: (1) konsultasi dan bimbingan dalam mengimplementasikan bidang akuntasi maupun pemasaran dan (2) konsultasi dan bimbingan dalam mengoperasionalkan website.

Pendampingan dilakukan dalam bentuk kunjungan lapangan kepada pengelola UKM sepatu untuk memantau dan membimbing peserta secara intensif. Alokasi waktu kegiatan pendampingan adalah minimal 2 minggu sekali selama kurun waktu 2 bulan. Tetapi bilamana pengelola UKM merasa perlu untuk melakukan konsultasi, maka dapat melakukannya diluar jadwal yang ditentukan, baik melalui konsultasi tatap muka maupun melalui telephon.

Kunjungan kepada pengelola UKM sepatu, dimaksudkan untuk bisa memantau secara langsung perkembangan peserta pelatihan dalam menerapkan materi pelatihan. Melalui direct consulting ini diharapkan peserta binaan dapat dipandu dalam menerapkan materi pelatihan.

Sedangkan metode komunikasi telepon sengaja dipilih, untuk memudahkan peserta latihan mengkonsultasikan materi pelatihan yang belum dipahami. Hal ini dipandang penting, mengingat UKM mitra kerja berada dalam jarak yang relatif jauh dari tim pelaksana pengabdian.

Pada pendampingan tahap awal, tim pelaksana masih memfokuskan pada penjelasan ulang tentang materi pelatihan yang belum dipahami oleh peserta, yaitu penerapan akuntansi dan tatacara mengoperasionalkan website. Selama pelaksanaan pendampingan, tim pendamping memberikan penjelasan materi melalui praktek langsung pada point materi yang belum dipahami oleh pengelola UKM sepatu. Dalam hal ini, pengelola UKM sepatu masih merasa kesulitan mengaplikasikan materi akuntansi dengan menggunakan bantuan program excel, mengoperasikan website dan mencari informasi tentang peluang pasar dengan memanfaatkan internet.

Pada pendampingan kedua, sudah ada kemajuan pada pengelola UKM dalam mengoperasionalkan website, sedangkan untuk program aplikasi akuntansi masih perlu ada bimbingan. Dalam pendampingan kali ini, tim pendamping hanya perlu mengoreksi bilamana terdapat kekeliruan dalam praktek dengan cara memperagakan secara langsung pada aspek-aspek yang belum dikuasai dalam mengoperasionalkan website. Selama pendampingan berlangsung, tim pelaksana banyak berdiskusi dengan mitra kerja tentang isi yang layak ditampilkan pada website dan manfaat menggunakan website. Disini pendamping juga menjelaskan bahwa perlu kejujuran dalam menampilkan spesifikasi produk dan harga jual pada website untuk menjaga kredibilitas usaha dan kepercayaan konsumen.

Selanjutnya pendampingan lapangan ketiga, tim pelaksana memonitor tentang konsistensi pengelola UKM sepatu dalam menerapkan akuntansi dan peningkatan kemampuan mereka dalam mengoperasionalkan website. Pada kunjungan kali ini sudah banyak kemajuan pada pengelola UKM dalam mengoperasionalkan website, namun untuk praktek akuntansinya belum ada kemajuan yang signfikan.

Sedangkan pendampingan langsung keempat, selain memonitor dan memandu pengelola UKM sepatu dalam mengoperasionalkan website maupun akuntansi, tim pendamping juga menginformasikan kepada pengelola UKM bahwa terdapat peluang bagi UKM untuk mengikuti pameran produk di berbagai provinsi di luar Jawa Timur. Untuk bisa mengikuti kegiatan pameran ini, maka UKM harus mendaftarkan diri ke Kamar Dagang dan Industri Propinsi Jawa Timur.

Selama pelaksanaan pembinaan dan monitoring, tanggapan peserta binaan cukup baik, hal ini terbukti dari banyaknya pertanyaan maupun pernyataan dari peserta binaan tentang penerapan materi pelatihan. Intensitas pertanyaan banyak muncul pada tatacara pengoperasian website dan terkadang juga tentang tatacara pembukuan yang benar. Melalui kegiatan pendampingan ini, bisa mengetahui kondisi sebenarnya yang dialami oleh pengelola UKM baik yang terkait dengan penerapan materi pelatihan maupun kegiatannya dalam pengelolaan usaha.

\section{PEMBAHASAN DAN EVALUASI KEGIATAN}

Sebagaimana telah dikemukakan pada paparan sebelumnya, bahwa pelaksanaan pengabdian kepada masyarakat ini diharapkan dapat meningkatkan kinerja pengelola UKM sepatu, utamanya dalam tatakelola keuangan dan bidang pemasaran dengan memanfaatkan teknologi dan informasi.

Pada saat pelaksanaan pelatihan, intruktur menyampaikan tentang urgensi dan manfaat pelatihan bagi upaya memperbaiki tatakelola usaha. Penjelasan awal ini dipandang penting untuk 
membuka wawasan berpikir mitra kerja yang selama 25 tahun sudah terbiasa mengelola usaha dengan sistem tradisional. Respons positif ditunjukkan peserta dengan kesungguhan dalam mengikuti seluruh sesi pelatihan. Mereka menjadi pembelajar aktif yang secara antusias meminta penjelasan atas materi yang belum dipahami maupun mengajukan pertanyaan atas materi yang dirasa kurang sesuai dengan pengalaman mereka selama mengelola usaha. Suasana pelatihan yang interaktif ini, sangat membantu instruktur untuk membangun komunikasi timbal balik dalam upaya memberikan penjelasan mendalam atas materi yang diberikan.

Secara normatif, aktivitas pelatihan seyogyanya dapat mengubah sistem berpikir dan prilaku individu peserta latihan. Namun secara faktual, perubahan sistem berpikir maupun prilaku individual peserta latihan bergerak agak lamban dan kurang sebangun dengan yang diharapkan. Kelambanan peserta dalam menginternalisasi materi pelatihan, disebabkan ada kesenjangan pengetahuan dan pengalaman antara instruktur dengan peserta. Peserta lebih banyak bertumpu pada pengalaman selama 25 tahun mengelola usaha, sedangkan instruktur terkadang terjebak pada aspek teoritis-normatif.

Kesejangan tersebut muncul, bukan terletak pada kualitas SDM yang rendah, melainkan lebih pada kurangnya pengetahuan dan ketrampilan tentang urgensi tatakelola usaha yang baik dan manfaat teknologi dan informasi bagi pemasaran. Sebab, mereka juga menyadari bahwa mengelola usaha secara professional sangat diperlukan bagi peningkatan kinerja bisnis ditengah persaingan yang ketat.

Materi pelatihan yang agak lamban dipahami oleh peserta adalah akuntansi dan metoda pengoperasian website. Namun menariknya, kedua materi tersebut mereka pandang penting dan direspons secara aktif. Sebab, materi akuntansi dan metoda pengoperasian website merupakan pengetahuan baru yang membutuhkan skill khusus untuk dapat menerapkannya. Selain itu mereka juga berpendapat bahwa akuntansi dan website sangat dibutuhkan untuk memajukan pengelolaan usaha.

Upaya memahamkan peserta pelatihan dalam menerapkan materi bukanlah pekerjaan sederhana. Sebab, mereka sudah terbiasa menerapkan metoda pengelolaan usaha secara konvensional dan telah terbukti berhasil. Untuk itu, tim pelaksana secara terus menerus dalam setiap kunjungan lapangan ataupun melalui kontak telpon berusaha memberi panduan kepada peserta atas materi yang belum dipahami. Khusus materi akuntansi, pengelola UKM sepatu merasa enggan untuk menerapkannya. Keengganan itu dipicu karena kekurang disiplinan dalam mencatat setiap transaksi yang dilakukan maupun mengarsip data-data keuangan. Mereka beranggapan bahwa pola lama saja sudah cukup memadai. Suasana ini segera bisa diatasi dengan komunikasi timbal-balik selama pelatihan maupun pendampingan. Jalinan komunikasi dua arah yang intensif ini ternyata banyak membantu efektivitas transformasi pengetahuan dan ketrampilan kepada peserta. Untuk bidang pemasaran lebih banyak difokuskan pada pemanfaatan teknologi dan informasi agar mereka dapat memperluas jaringan pemasarannya dengan biaya murah.

Sedangkan pada tahap pendampingan, tim pelaksana melakukan pendampingan langsung melalui enam kali kunjungan kelokasi mitra kerja. Pendampingan dengan kunjungan langsung ini bertujuan agar dapat memantau secara langsung perkembangan kemampuan mereka dalam menerapkan materi pelatihan. Selama melakukan pendampingan, tim pelaksana memfokuskan pada pemanduan tatacara menerapkan materi yang belum dipahami, yakni pengoperasian website dan akuntansi. Kedua materi ini memang memerlukan perhatian khusus selama pendampingan. Sebab, peserta pelatihan masih belum dapat menerapkan secara optimal dikarenakan keterbatasan waktu untuk mempelajarinyan; padahal kedua materi ini diperlukan oleh peserta latihan dalam upaya meningkatkan kinerja pengelolaan UKM sepatu dan memperluas jangkauan wilayah pemasarannya.

Namun demikian, untuk dapat mendeteksi tingkat keefektifan dan kemanfaatan kegiatan pengabdian ini, maka perlu melakukan evaluasi atas semua rangkaian pelaksanaannya. Evaluasi dilaksanakan dengan cara mewawancarai peserta untuk mengetahui keefektifan pelaksanaan pelatihan maupun pendampingan serta berbagai hal yang terkait dengan pelaksanaanya, seperti jadwal pelatihan, metode pelatihan, penguasaan instrukstur terhadap materi sampai tingkat kemanfaatan dan tindak lanjut pelatihan itu sendiri. Jawaban yang diperoleh dari peserta pelatihan dapat dilihat pada tabel 1.

Jawaban tersebut di atas menunjukkan bahwa peserta pelatihan memberikan tanggapan positif terhadap kegiatan ini dan merasa memperoleh manfaat dari kegiatan ini bagi upaya meningkatkan kinerja pengelolaan bisnis. Kegiatan pengabdian ini memberikan nilai tambah bagi pengusaha UKM sepatu, utamanya dalam bidang manajemen pe- 
masaran, akuntasi dan penggunaan website untuk memasarkan produk. Respon positif dari peserta latihan ini disertai pula dengan keinginan agar ada tidak lanjut pelatihan dalam bentuk bantuan konsultasi, baik dalam penerapan materi pelatihan maupun pemecahan masalah.

Tabel 1. Tanggapan pelaksanaan pelatihan

\begin{tabular}{|c|c|}
\hline Indikator & Jawaban \\
\hline Jadwal pelaksanaan & $\begin{array}{l}\text { Sesuai dengan waktu } \\
\text { yang direncanakan }\end{array}$ \\
\hline Metoda penyampaian & Mudah dipahami \\
\hline $\begin{array}{l}\text { Penguasaan materi oleh } \\
\text { instruktur }\end{array}$ & Menguasai \\
\hline $\begin{array}{l}\text { Durasi waktu untuk } \\
\text { tanya-jawab }\end{array}$ & Cukup \\
\hline Kemanfaatan pelatihan & Sangat bermanfaat \\
\hline $\begin{array}{l}\text { Keterserapan materi oleh } \\
\text { peserta }\end{array}$ & $\begin{array}{l}\text { Peserta merasa belum } \\
\text { optimal }\end{array}$ \\
\hline $\begin{array}{l}\text { Metoda pendampingan } \\
\text { Lapang }\end{array}$ & Sudah sesuai. \\
\hline $\begin{array}{l}\text { Urgensi pendampingan } \\
\text { lapang }\end{array}$ & Sangat perlu \\
\hline
\end{tabular}

Sumber: kuesioner evaluasi, Oktober 2013

Ikhtiar pelaksana pengabdian melalui pelatihan dan pendampingan intensif kepada pengelola UKM sepatu, diharapkan dapat menambah pemahaman pada pelaku usaha tentang bagaimana metoda pengelolaan usaha secara lebih baik dan bagaimana pula memanfaatkan teknologi informasi bagi upaya meningkatkan kinerja UKM yang mereka kelola, utamanya dalam memperluas jaringan pemasaran produk ditengah pasar lokal maupun internasional yang semakin terbuka sehinga mereka bisa tetap survive bahkan bisa berkembang lebih maju.

\section{KESIMPULAN DAN SARAN}

\section{Kesimpulan}

Kesimpulan pelaksanaan kegiatan pengabdian kepada masyarakat bagi pengelola UKM sepatu adalah sebagai berikut:

1. Pengelola UKM sepatu merespons positif pelaksanaan kegiatan pelatihan dan pendampingan. Ini ditunjukkan dari keaktifan mereka mengikuti keseluruhan tahapan pelatihan maupun pendampingan.

2. Metoda komunikasi non formal sangat membantu mengefektifkan pemahaman pengelola UKM sepatu tentang urgensi tata kelola yang baik dalam bidang keuangan, pemasaran dan penggunaan website.

3. Kegiatan pendampingan kepada pengelola UKM sepatu merupakan sarana penting dalam menunjang efektivitas penerapan materi akuntansi dan pengoperasian website.
4. Terdapat perubahan prilaku usaha yang positif pada pengelola UKM sepatu dalam bentuk kesediaan melakukan pembukuan usaha maupun menggunakan teknologi dan informasi (meskipun belum mahir) untuk pemasaran.

5. Pemanfaatan teknologi dan informasi untuk pemasaran direspons lebih cepat oleh pengelola UKM sepatu dibandingkan bidang tata kelola keuangan.

\section{Saran}

1. Metode pelaksanaan pengabdian kepada masyarakat perlu fleksibelitas dalam pendekatannya yakni dalam metoda pelatihan, komunikasi maupun pendampingan dilakukan dengan menkombinasikan pendekatan formal maupun non formal.

2. Komunikasi proaktif kepada peserta perlu dilakukan secara intensif agar mereka bersedia untuk meluangkan waktu mengkaji kembali materi pelatihan dan menerapkannya.

3. Materi pelatihan perlu dirancang dengan bahasa yang sederhana dan mudah dipahami oleh peserta.

4. Tim pelaksana hendaknya berperan sebagai fasilitator sekaligus motivator agar proses pelatihan maupun pendampingan kepada pengelola UKM dapat berjalan efektif.

\section{DAFTAR PUSTAKA}

Dinas Koperasi, PKM Propinsi Jawa Timur, 2002, Laporan Pelaksanaan Program Pengembangan Koperasi, dan PKM di Jawa Timur tahun Anggaran 2001.

Achmadi, M. (1995). Aspek Pengembangan dan Permasalahan Usaha Kecil, Cetakan pertama, Erlangga Jakarta.

Tambunan, Tulus T.H. (2008). Usaha Kecil dan Menengah di Indonesia Beberapa Isu Penting. Salemba Empat. Jakarta.

Mubyarto, Strategi pemulihan Ekonomi Indonesia dan Model penguatan Ekonomi Rakyat, Makalah yang disampaikan pada seminar Pemberdayaan Ekonomi Rakyat: Strategi Revitalisasi Perekonomian Indonesia di CSIS, Jakarta, 21 Februari 2001.

Morck, F., M. Hall dan E.Vall. (2003). Banking and Venture Capital Matrick, Work Package 7. European Commision Information Society Technologies Programme IST 2000-29665.

Robbins, S.P. \& Judge A.Timothy. (2009). Organizational Behavior: $13^{\text {th }}$ Edition. Pearson Prentice-Hall. New Delhi.

Senge, P.M. (1994).The Fifth Dicipline: The Art and Practice of Learning Organization. Double D. New York. 